\title{
パイロリティック・グラファイトの合成と物性
}

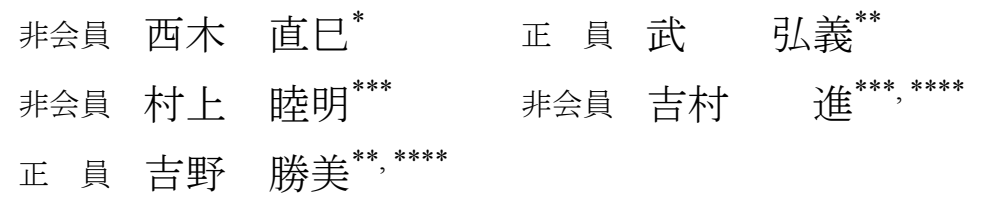

\section{Synthesis and Characterization of Pyrolytic Graphite from Heat-treated Polyimide}

Naomi Nishiki ${ }^{*}$, Non-member, Hiroyoshi Take**, Member, Mutsuaki Murakami***, Non-member, Susumu Yoshimura ${ }^{* * *},{ }^{* * * *}$, Non-member, Katsumi Yoshino ${ }^{* * * * * *}$, Member

High-temperature heat treatment of polyimide (Kapton) film yielded a highly oriented graphite film, composed of nearly ideal thin graphite layers with $6 \sim 7 \mathrm{~nm}$ in thickness. The graphite films assumed various characteristic forms in appearance depending on heat-treatment. The graphite films containing minute vesicles within the film were obtained starting from a thick polyimide film, which yielded a flexible graphite sheet with excellent physical and mechanical properties compared with commercialized, expanded graphite sheets.

キーワード : ポリイミド, カプトン, グラファイト, 高温処理, 柔軟性

Keywords : polyimide, Kapton, graphite, heat treatment, flexibility

\section{1. 緒言}

グラファイトは高耐熱・軽量・高導電性・高弾性である ため, 電極材料, ガスケットなどの工業材料として，また 断熱材や航空宇宙，スポーツ用途等の複合材料等として広 く使われている。また，最近では，フラーレンやナノチュ ーブが注目を集め, 電子回路, ディスプレイ用電子放出電 極，二次電池電極，医療分野等への応用が検討されている。 これに対して人工のグラファイトシートは，従来一般に天 然に産出する微小結晶から作製されたエキスパンドグラフ アイトをシート化して使われてきた。しかし，近年いくつ かの高分子材料の熱処理によって直接グラファイトフィル

* 松下電器産業 (株) 生産技術本部

干571-8502 門真市松葉町 2-7

Processing Engineering Development Center, Matsushita Electric Industrial Co., Ltd.

2-7 Matsuba-cho, Kadoma 571-8502

** 大阪大学 大学院 工学研究科

干565-0871 吹田市山田丘 2-1

Department of Electronic Engineering, Graduate School of Engineering, Osaka University

2-1 Yamadaoka, Suita 565-0871

*** 松下技研 (株) 新素材研究所

干214-8501 川崎市多摩区東三田 3-10-1

Advanced Materials Research Laboratory, Matsushita

Research Institute Tokyo, Inc.

3-10-1 Higashimita, Tama-ku, Kawasaki 214-8501

**** 長崎総合科学大学

長崎市網場町 536

Nagasaki Institute of Applied Science

536 Aba-cho, Nagasaki-shi, Nagasaki 851-0193
ムを製造する方法が開発され，この方法で得られたグラフ アイトフイルムは従来に比べてはるかに優れた物性值を有 している事が明らかになった。そのため工業材料としての 価值が認められ，特にポリイミドから得られたグラファイ トフィルムは高熱伝導性と異方性を利用したノートパソコ ンや携帯電子機器用の熱伝導シートとして使用され始めて いる。

高分子材料の炭素化, グラファイト化の研究は古くから 行われ，例えば繊維状のポリアクリロニトリル（PAN）を 用いた炭素繊維, グラファイト繊維は大きな産業になって いる。これに対して高分子フィルムから直接高品質のグラ ファイトフィルムが得られることは 1985 年に発表された が(1), 現在でも高品質のグラファイトフィルムに転化できる 高分子材料としては, ポリオキサジアゾール (POD), ポリ イミド（PI）など数種類の高分子材料が知られているだけ である。例えば，ポリイミド，ポリオキサジアゾール等を 出発高分子とするグラファイト化は, 吉村・村上 ${ }^{(2)(3)}$, 稲垣・ 菱山(4) (7), 長谷川(8)(9)塩谷(10)らによって報告されており, ポリパラフェニレンビニレン等の高分子を出発原料とする ものについては, 大西(11) (13), 吉野(14)(15)らによって報告さ れている。これらの高分子の中でポリイミドを出発原料と したグラファイトフィルムについては最も多く研究がなさ れている。例えば，菱山らは得られたグラファイトフイル ムの物性についていくつかの報告を行っており，長谷川ら はポリイミド原料のグラファイト化に及ぼす影響につい 
て, 特にポリイミド分子の配向性がグラファイト化に及ぼ す影響について報告している。また，村上らは複数枚のポ リイミドフィルムを加圧熱処理してグラファイトブロック を作製する技術を開発した ${ }^{(16)}$ 。このグラファイトブロック は気相堆積法による $\mathrm{HOPG}^{(17)}$ と同等の高配向性を有してお りX線のモノクロメーターとして使用されている(18)。また， 星らはポリイミドから得られるグラファイトフィルムが優 れた機械的・熱的性質を持っていることを報告している(19)。 さらに, インターカレーションによって飛躍的に導電率が 向上寸る特性(20)(21)や特殊な形態(22)を持つことも報告され ている。しかしながら，なぜこれらの限られた高分子のみ が良質のグラファイトフィルムに転化できるのか，あるい はそのグラファイト化反応が如何にして進行するのか，な ぜ，この方法で得られたグラファイトが優れた機械的・熱 的性質を持つのか等, その詳細については不明な点も多い。

本稿では，ポリイミドを出発原料として取り上げ，導電 率の変化, 透過X線回折像の変化, S E M 観察からそのグ ラファイト化のプロセスを検討する。また，熱処理条件を 制御することで，外観の異なるグラファイトシートが製造 でき，この現象を利用してグラファイトとしての高い品質 を保ちながら柔軟で弾力性のあるグラファイトシートの製 造方法を確立したので報告する。

\section{2. 実験方法}

$\langle 2 \cdot 1\rangle$ 出発高分子材料 出発高分子材料として, ポ リイミドフィルム（デュポン社製，Kapton®フィルムHタ イプ）を用いた。Kapton®フィルムには，30H（厚さ 7.5 $\mu \mathrm{m}), 50 \mathrm{H}$ (厚さ $12.5 \mu \mathrm{m}$ ), $100 \mathrm{H}$ (厚さ $25 \mu \mathrm{m}), 200 \mathrm{H}$ (厚さ $50 \mu \mathrm{m}$ ), $300 \mathrm{H}$ (厚さ $75 \mu \mathrm{m}$ ), $500 \mathrm{H}$ （厚さ $125 \mu$ m) がある。これらのポリイミドフィルムは, 同じように熱 処理をしても外観（表面）の状態に大きな差が生じる。薄 い原料フィルムから作製したグラファイトフィルムは平滑 な外観を持ち, 厚いフィルムから作製した物は表面の凹凸 が激しくなる傾向がある。200H は, 熱処理条件を変えるこ とで外観を作り分けできることが分ったので，これを標準 試料として以下の実験を行った。

$\langle 2 \cdot 2\rangle$ 熱処理方法 熱処理には㑣進成電炉製作所製 の管状カーボンヒーターを用いた横型電気抵抗加熱炉を使 用した。ポリイミドフィルムは, 図 1 のような等方性カー ボンブロックを加工した坩堝に入れ，ロータリーポンプで アルゴンガスに真空置換後, アルゴンガスフロー中で熱処 理を行った。ガスフロー中で行った理由は, 酸素の混入を 減らし熱処理過程で発生するガスを除去するためである。 試料は $50 \times 30 \mathrm{~mm}$ とし, 一定の速度で昇温, 最高処理温度

(HTT) 到達後 1 時間保持し自然降温させた。坩堝中の押 さえ板の荷重（約 $200 \mathrm{~g} /$ 枚）が試料にかかるが, 最上段と 最下段の外観や物性值に差異が見られないため, その影響 は無視した。

$\langle 2 \cdot 3\rangle$ 評価方法 導電率の測定は, Quantum Design 社製 PPMS を用いて, 標準的な 4 端子法により行なった。

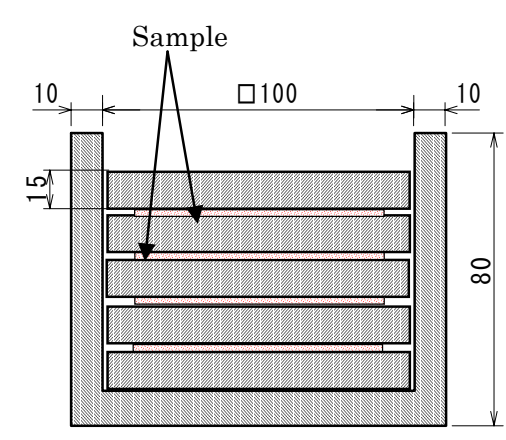

図 1 熱処理用カーボン坩堝

Fig. 1. Carbon pot for heat treatment.

音速は, 幅 $5 \mathrm{~mm}$ 長さ $30 \mathrm{~mm}$ に切り出した試料の一端を加 振器に取り付け, 他端の変位速度をレーザー変位計により 測定し, 計算でヤング率 $\mathrm{E}$ を求めた。密度 $\rho$ は外形寸法と 重量から求め, 下記の式 1 により音速值 c とした。

$$
c=\sqrt{\frac{\mathrm{E}}{\rho}}
$$

$\mathrm{X}$ 線回折像の測定は, マックサイエンス社製 $\mathrm{MX} \mathrm{P}{ }^{3}$ によ って行った。透過電子顕微鏡の観察は, 日本分光 J EM$400 \mathrm{~F}$ を用いて行った。耐折試験は, 東洋精機㑣社製M I T 耐揉疲労試験機 $\mathrm{D}$ 型を用い, 曲げ半径 $2 \mathrm{~mm}$, 曲代角度 \pm 90 で曲げ回数により比較評価を行った。

\section{3. 実験の結果及び考察}

〈3.1〉処理温度による特性変化ポリイミドフィル ムの熱処理による外見上の変化はおよそ次の様に進行す る。500〜 $600^{\circ} \mathrm{C}$ の温度領域でポリイミドの黄色い透明色は 不透明黒色に変化し, $800^{\circ} \mathrm{C}$ 付近ではガラス光沢のある黒色 となる。1000 $2000^{\circ} \mathrm{C}$ 間では外見上の変化はほとんどな いが， $2200^{\circ} \mathrm{C}$ を超えた付近でガラス光沢は消失する。ポリ イミドの熱分解は 500 $600^{\circ} \mathrm{C}$ で開始し, 分解ガスの発生は $1200^{\circ} \mathrm{C}$ までにほぼ完了する。試料の面方向のサイズはポリ イミドフィルムの熱分解領域で 76〜 77\%に收縮するが厚さ は約 $94 \%$ と変化が小さい。その後, 試料のサイズは $2400^{\circ} \mathrm{C}$ あたりまでほとんど変化しないが, $2400^{\circ} \mathrm{C}$ 以上の温度領域 では試料の面方向のサイズが初期に対して $87 \sim 88 \%$ に戻 り, 厚さ方向は初期に対して約 $60 \%$ に縮むことが観察され た。すなわちこの領域では試料の面方向と厚さ方向で異方 的な寸法変化を示寸。図 2 には昇温速度 $7 \mathrm{deg} / \mathrm{min}$ で熱処理 したフィルム面方向の導電率の処理温度依存性を示す。導 電率は $1000^{\circ} \mathrm{C}$ までの炭素化の過程で急激に増加するが, そ の後 $1300^{\circ} \mathrm{C}$ から $2200^{\circ} \mathrm{C}$ 範囲ではあまり変化しない。しか し, $2200^{\circ} \mathrm{C}$ 付近から再び増加し, この領域でのグラファイ 卜化反応が進行していることが予想できる。

図 3 にはフィルム面方向の音速およびヤング率の処理温 度依存性を示す。音速值やヤング率は $\mathrm{HTT}=2400^{\circ} \mathrm{C}$ を超え た付近から急速に上昇している。グラファイトの $\mathrm{a}-\mathrm{b}$ 面 方向は高い音速值，高いヤング率を持つことが知られてい 


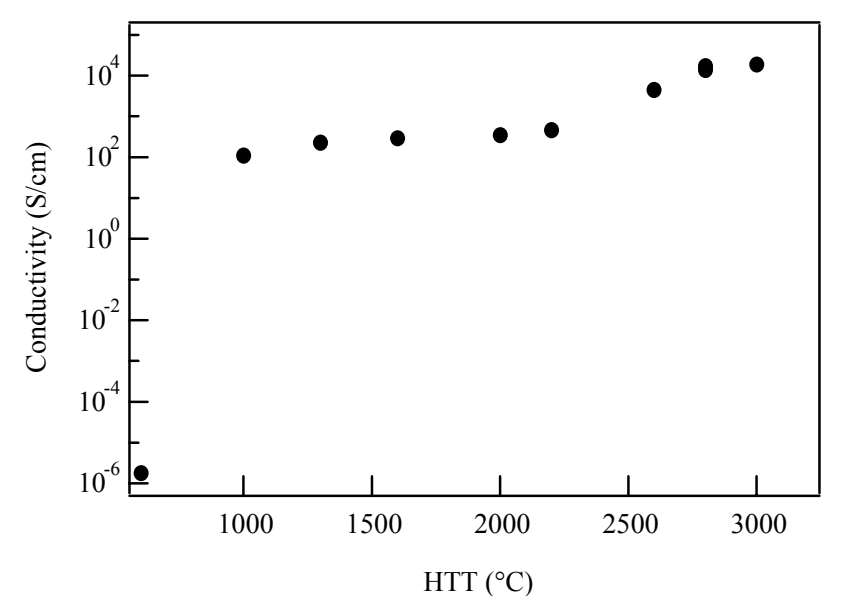

図 2 室温における導電率の熱処理温度依存性

Fig. 2. Dependence of room-temperature electrical conductivity on heat-treatment temperature (HTT).

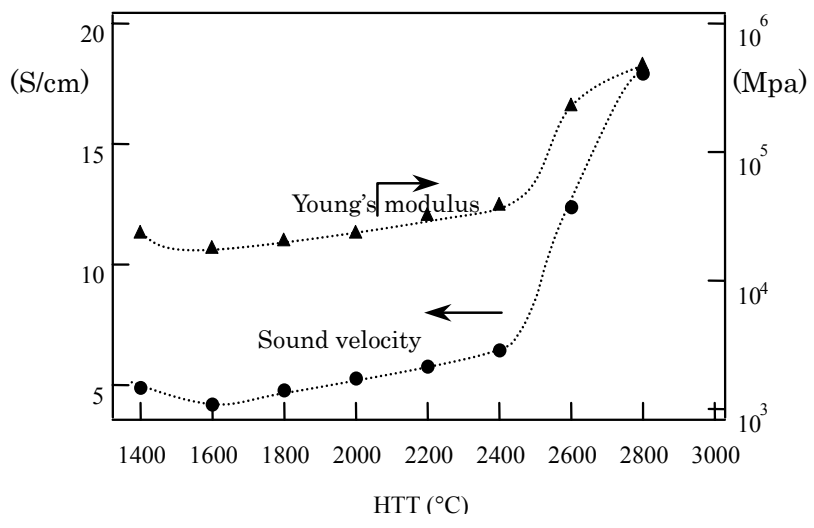

図 3 音速とヤング率の熱処理温度依存性

Fig. 3. Dependence of sound velocity and young's modulus on HTT.

るので，この温度領域での音速值やヤング率の上昇は直接 的に, グラファイトの層構造がフィルム面方向に平行に発 達して行く状況を示している。

以上の変化からポリイミドフィルムの炭素化は $1000^{\circ} \mathrm{C}$ 付 近までにほぼ完了し， $2400^{\circ} \mathrm{C}$ 付近からフィルム面と平行方 向な方向へのグラファイト層構造の発達が始まると考えら れる。

〈3·2〉熱処理によるX 線回折像の変化 図 4 には $\mathrm{HTT}=600 \sim 2000^{\circ} \mathrm{C}$ の温度領域の, 図 5 には $\mathrm{HTT}=2000 \sim$ $3000^{\circ} \mathrm{C}$ の温度領域における透過 X線回折像の変化を示す。 低角度側で高い強度を示しているのは，X 線の入射角が浅 く, 試料の表面状態の影響により見かけ上強度が大きくな っていると考える。これらの回折像にはいずれも(002)の弱 い回折線が観察されている。グラファイト(002)回折線の回 折角 $(2 \theta)$ は網面間の距離を示し，グラファイトの層構造が フィルム面方向に完全に平行ならば透過 X線回折像には出 現しない回折線である。また，グラファイト化の進行と共

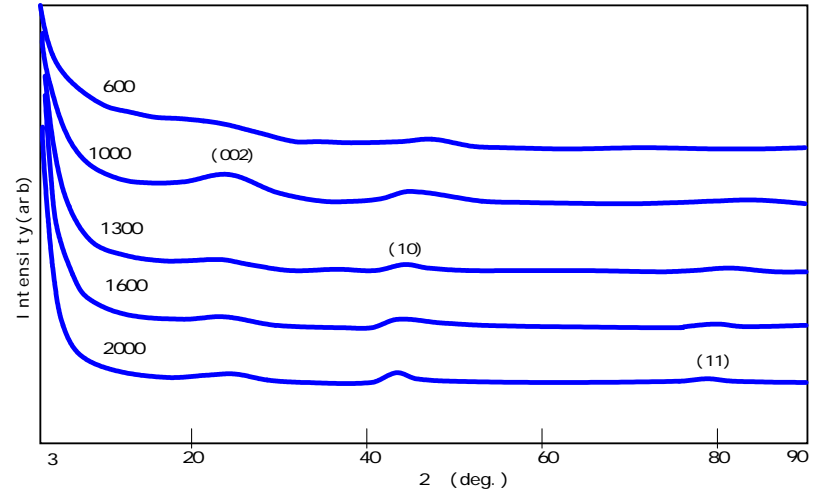

図 4 熱処理温度による透過 $\mathrm{X}$ 線 $(\mathrm{CuK} \alpha)$ 回折像の変化 $\left(600 \sim 2000^{\circ} \mathrm{C}\right)$

Fig. 4. Change in transmitted X-ray $(\operatorname{CuK} \alpha)$ diffraction patterns with progressive HTT's from 600 to $2000^{\circ} \mathrm{C}$.

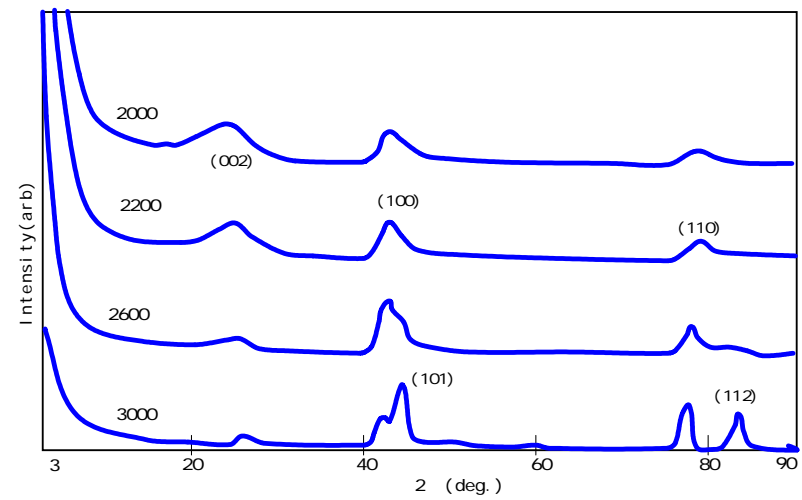

図 5 熱処理温度による透過 $\mathrm{X}$ 線 $(\mathrm{CuK} \alpha)$ 回折像の変化 $\left(2000 \sim 3000^{\circ} \mathrm{C}\right)$

Fig. 5. Change in transmitted X-ray $(\mathrm{CuK} \alpha)$ diffraction patterns with progressive HTT's from 2000 to $3000^{\circ} \mathrm{C}$.

に完全な層構造が形成されるに伴って広角度側にシフトす る。従って, この(002)回折線の出現の有無, 出現位置, 回 折線の鋭さを観察すれば，ある程度グラファイト面の発達 の様子を知ることが出来る。

$1000^{\circ} \mathrm{C}$ (002)回折線は非常にブロードでそのピーク位 置は，およそ $2 \theta=23.0^{\circ}$ であり，この值から面間距離を見 積もると $0.3864 \mathrm{~nm}$ となった。(正確にはこの様なブロード な回折線の場合にはシリコンを内部標準として使用したラ イン補正が必要であるが，ピークが弱いのであえて補正は しなかった）この值はグラファイト単結晶值 $(0.3354 \mathrm{~nm})$ に比べ大きな值となっている。この事から $1000^{\circ} \mathrm{C}$ 程度で処 理した炭素は完全な非晶質炭素ではなく部分的に小さな炭 素六角網目構造の存在する構造であることがわかる。グラ ファイト構造が形成された場合, この(002)回折線(002)は本 来非常に強い強度を持つものであるが， $1000^{\circ} \mathrm{C}$ 処理の(002) 回折線は(10)回折線に比べて 2 倍程度の強度でしか出現し 
ていない。 $1000^{\circ} \mathrm{C}$ 付近で形成される炭素六角網目構造は全 体としてはフィルム面方向に配向しており，そのために強 度が弱くなったと考えられる。これに対して $\mathrm{HTT}=1300^{\circ} \mathrm{C}$, $1600^{\circ} \mathrm{C}$ 回折像からは(002)回折線が消失する傾向にある。 網目構造の発達が進行した場合には(002)回折線の強度は強 くなり, 網目構造がフィルム面と平行に配向する場合には, その回折線強度は弱くなるので, この温度領域では網目構 造がフィルム面と平行に配向する現象が優先的に起きてい ると予想できる。これらの事は，この $2000^{\circ} \mathrm{C}$ 以下の温度領 域における制限視野回折測定からも確認されている(16)。図 5 に示した $\mathrm{HTT}=2000 \sim 3000^{\circ} \mathrm{C}$ 以上の温度領域の回折像にお いても弱い(002)回折線が観察され，処理温度の上昇と共に 広角度側にシフトしている。例えば， $\mathrm{HTT}=3000^{\circ} \mathrm{C}$ の試料 における(002)回折線のピーク位置は $2 \theta=26.0^{\circ}$ であり， この值から見積もった層間距離は $0.3424 \mathrm{~nm}$ である。ちな みに同じ試料を反射法によって測定した(002)回折線を用い て計算した層間距離は $0.3358 \mathrm{~nm}$ であり, 単結晶值に極め て近い值であった。この温度領域ではグラファイト構造の 発達が優先的に起きていると考えられる。グラファイト(10) 回折線は，すでに $2000^{\circ} \mathrm{C}$ 処理温度で現れているが，この 回折線が(100) と(101)に分裂し始めるのは $2600^{\circ} \mathrm{Cからであ}$ り，明確に別れるのは $3000^{\circ} \mathrm{C}$ 至ってからである。同様に $3000^{\circ} \mathrm{C}$ では(11)回折線も(110) と(112)の二本に別れて出現 する。この様な回折線の変化は，2000 $2200^{\circ} \mathrm{C}$ の間に形成 されたグラファイト構造においては炭素六角網目構造が平 行に積み重なってはいるが，その重なりに規則性がないこ とを示し, $2600^{\circ} \mathrm{C}$ 上ではグラファイト層がフィルム面方 向に配列するばかりでなく, 層間の垂直方向の規則性を持 つグラファイト構造が完成したことを示している。

\section{〈3.3〉透過電子顕微鏡による観察図 6 , 図 7 及び図} 8 は透過型電子顕微鏡 (TEM) で観察したフィルム断面の グラファイト構造発達の様子である。それぞれ, 図 6 は $\mathrm{HTT}=2000^{\circ} \mathrm{C}$, 図 7 は $2600^{\circ} \mathrm{C}$, 図 8 は $3000^{\circ} \mathrm{C}$ で熱処理し た試料の観察結果である。

$\mathrm{HTT}=2000^{\circ} \mathrm{C}$ の $\mathrm{TEM}$ 像（図 6）には波打った形のグラフ アイト前駆体の層構造が観察されており, 図中のいくつか の矢印で示した様に，この層は全体としてはフィルム面に 平行な方向に配向している。このようなグラファイト前駆 体の配向は出発原料であるポリイミドフィルムにおいて分 子がフィルム面方向に配向していることを反映したもので あろうと考えられる。事実, Kapton®フィルムはフィルム 面方向に分子配向した高弾性フィルムであることが知られ ている。

$\mathrm{HTT}=2600^{\circ} \mathrm{C}$ の $\mathrm{TEM}$ 像（図 7）ではグラファイトの層構 造はより明確になりその層も長くなる。すなわちグラファ イト前駆体が相互に平行になるようにつながりグラファイ 卜構造を形成して行くと考えられる。この過程でグラファ イト層がフィルム面にほぼ平行に形成されるのは, $2000^{\circ} \mathrm{C}$ 付近でのグラファイト前駆体が全体としてはフィルム面方 向に配向していることによるのであろう。これらは易グラ

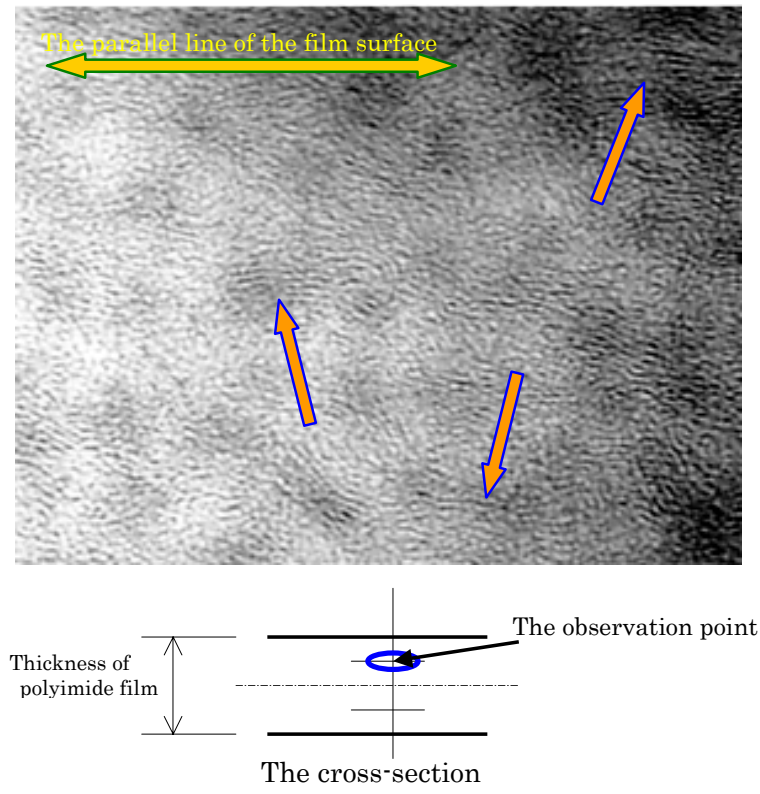

図 $6 \mathrm{HTT}=2000^{\circ} \mathrm{C}$ 処理フィルムの断面 TEM 像（002 格子像）

Fig. 6. TEM image of (002) lattice observed from the cross-sectional direction (for $\mathrm{HTT}=2000^{\circ} \mathrm{C}$ ).

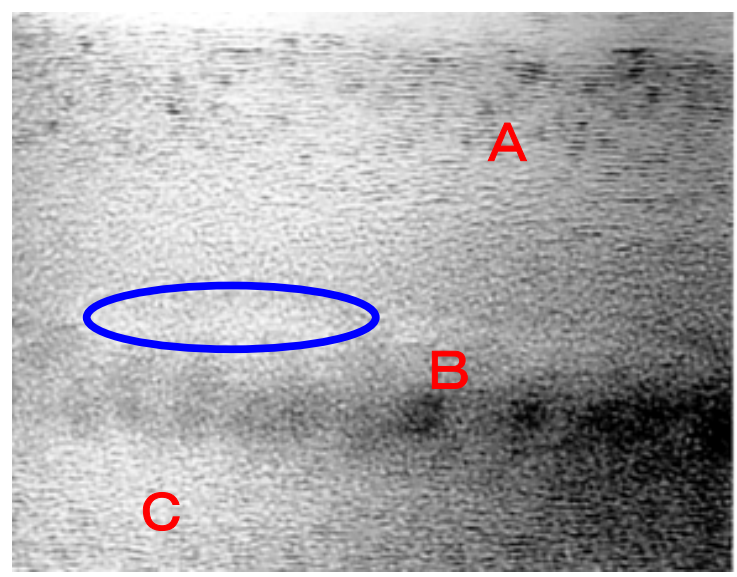

図 $7 \mathrm{HTT}=2600^{\circ} \mathrm{C}$ 処理フィルムの断面 TEM 像（002 格子像）

Fig. 7. TEM image of (002) lattice observed from the cross-sectional direction (for $\mathrm{HTT}=2600^{\circ} \mathrm{C}$ ).

ファイト化炭素における典型的な反応であり, 事実, 配向 のほとんど無いポリイミドフィルムでは難グラファイト化 カーボンとなり，良質のグラファイトには転化できないこ とが知られている。

この温度領域で注目すべき点はフィルムの厚さ方向でグ ラファイト化が比較的良く進行している部分 (AとC), と グラファイト化の進行が遅い部分（B）が層状に存在して いることである。フィルム内部においてグラファイト化反 応は不均一に進行することが分る。また, グラファイト層 


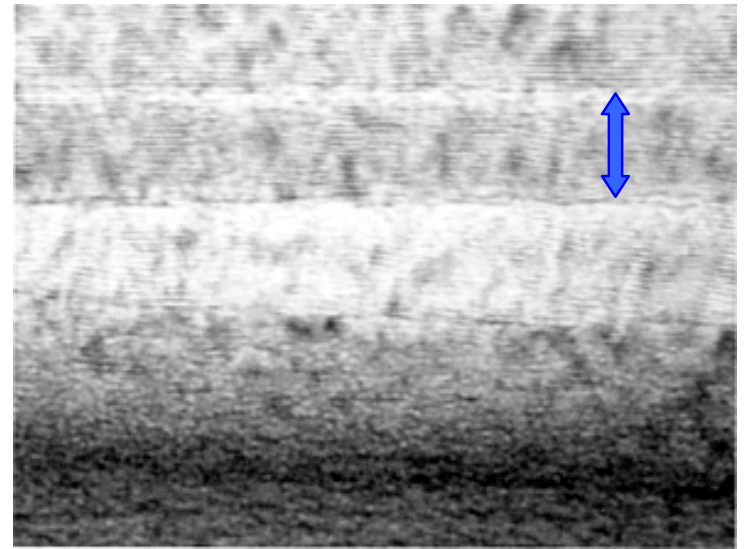

図 $8 \mathrm{HTT}=3000^{\circ} \mathrm{C}$ 処理フィルムの断面 TEM 像（002 格子像）

Fig. 8. TEM image of (002) lattice observed from the cross-sectional direction (for $\mathrm{HTT}=3000^{\circ} \mathrm{C}$ ).

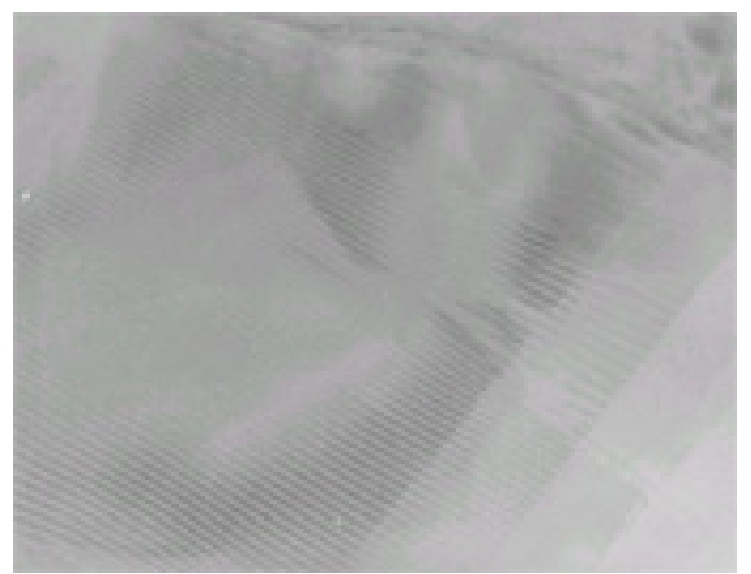

図 $9 \mathrm{HTT}=3000^{\circ} \mathrm{C}$ 処理フィルム面の $\mathrm{TEM}$ 像 (110 格子からのモアレ像)

Fig. 9. TEM dark-field image of the (110) lattice viewed from the direction normal to the basal plane $\left(\mathrm{HTT}=3000^{\circ} \mathrm{C}\right)$

の比較的良く発達した部分でもグラファイト層の不整合が 生じている部分が観察され（図中円で囲んだ部分），まだ不 完全なグラファイト構造であることが分る。

$\mathrm{HTT}=3000^{\circ} \mathrm{C}$ での TEM 像（図 8）では，およそグラファ イトの層数にして 20 層（すなわち $\mathrm{Lc}=6 \sim 7 \mathrm{~nm}$ ）程度の極 めて薄い良質のグラファイト層（図中の矢印）が積み重な った構造が観察される。この層の厚さは熱処理条件が同じ なら，ほとんど変わらないという特徽を持っており，グラ ファイト層における面方向の長さ La は極めて大きい。

図 9 は $3000^{\circ} \mathrm{C}$ 熱処理試料をさらに $0.1 \mu \mathrm{m}$ 以下に剥離し た試料の表面方向からの TEM 観察像である。面方向からの TEM 像には高結晶性の薄いグラファイト層がランダムに 重なった場合のモアレ回折が観察され，さらにこの部分の 制限視野回折の結果から，上記の薄いグラファイト層の間
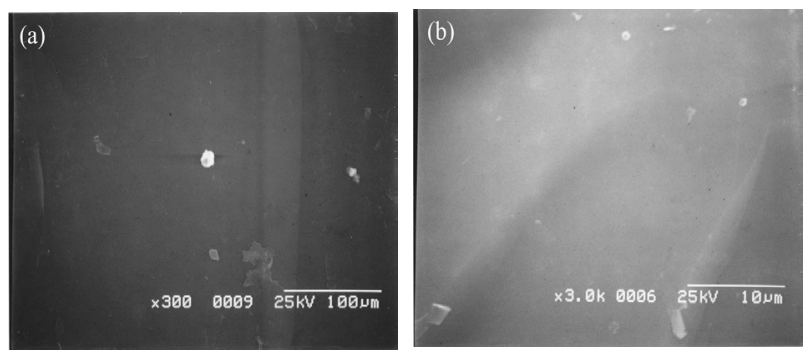

図10 グラファイト表面の SEM 写真 (熱処理条件(3)(表 1))

Fig. 10. SEM image of the graphite film obtained by a heat-treatment condition (3) (See Table 1).
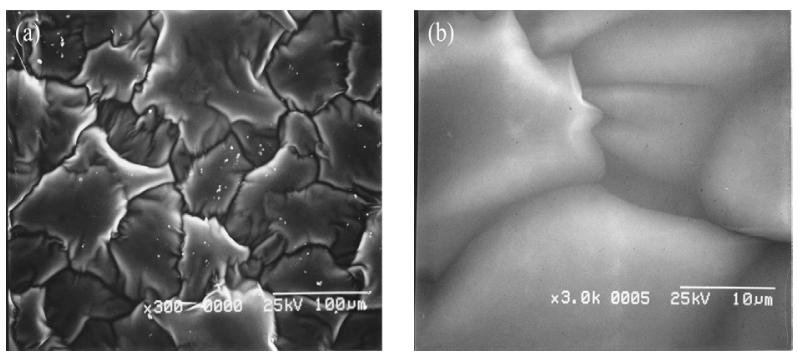

図 11 グラファイト表面の SEM 写真 (熱処理条件(2)(表 1))

Fig. 11. SEM image of the graphite film obtained by a heat-treatment condition (2) (See Table 1).

には結晶関係は存在せず，互いに独立して存在していると 考えられる。この様な観察は図 8 における TEM 観察とよく 一致している。以上の結果から，グラファイト化ポリイミ ドは極めて薄い高品質グラファイト膜の集合体であるとみ なすことができる。

〈3.4〉昇温条件の影響 前項での観察からグラファ イト化ポリイミドは極めて薄い $(\mathrm{Lc}=6 \sim 7 \mathrm{~nm}$ 程度 $)$ 良質 のグラファイト層の集合体であることが分った。この様な グラファイト層を持つフィルムからは柔軟性に富む高品質 のグラファイトフィルムの製造が可能であると考え，プロ セスの検討を行った。

Kapton®フィルム $200 \mathrm{H}$ を用いて昇温速度を変更しその 影響を検討した結果， $1000^{\circ} \mathrm{C}$ 以下の温度領域と 1000 $3000^{\circ} \mathrm{C}$ の温度領域での昇温速度を変えることによって得ら れるグラファイトフィルムの外観が大きく変化することが 分った。代表的なフィルム表面の SEM 写真を図 10(a), (b), 図 11(a)，(b)に示した。図 10 は表面にほとんど凹凸のない 硬いフィルムであり, 図 11 は表面に凹凸の発生した状態(発 泡したような状態）にあるフィルムである。この図 11 の状 態がさらに進行すると, グラファイトはボロボロの断片に なりフィルム状態を保持することができなくなる。我々は, この様な試料形状の違いは内部からのガス発生による影響 と考え, まず発生ガスを制御することを目的に熱処理プロ セスの検討を行った。当初, $1000^{\circ} \mathrm{C}$ 以下の温度領域におけ 
表 1 昇温速度が熱処理試料の厚さと

見かけ密度に及ぼす影響 $\left(\mathrm{HTT}=2800^{\circ} \mathrm{C}\right)$

Table 1. Effect of heat-treatment condition on thickness and density of graphite films $\left(\mathrm{HTT}=2800^{\circ} \mathrm{C}\right)$.

\begin{tabular}{|c|c|c|c|c|}
\hline \multicolumn{3}{|c|}{ Heat-treatment condition } & \multirow{2}{*}{$\begin{array}{c}\text { Thickness } \\
\text { after heat } \\
\text {-treatment }\end{array}$} & Density \\
\hline (1) & $1.5(\mathrm{deg} / \mathrm{min})$ & $5(\mathrm{deg} / \mathrm{min})$ & $29(\mu \mathrm{m})$ & 1.6 \\
\hline (2) & 1.5 & 20 & 55 & 0.8 \\
\hline (3) & 7 & 5 & 23 & 2.0 \\
\hline (4) & 7 & 20 & 22 & 2.1 \\
\hline
\end{tabular}

る昇温速度は遅いほどゆっくりと分解が進行し, 安定した 品質の試料ができると考えた。しかし予想に反して，この 温度領域での昇温速度が遅い場合には発泡の進んだボロボ ロの状態になり，むしろ，この領域の昇温速度を上げるこ とによって平滑な試料が得られる傾向があることが分っ た。これは, 昇温速度が遅い時にはより緻密なガラス状炭 素が形成され, $1000^{\circ} \mathrm{C}$ 以上での発生ガスの逃げ道が遮断さ れるために生じると考えている。この結果から, 昇温速度 の遅い条件を $1.5 \mathrm{deg} / \mathrm{min}$, 早い条件を $7 \mathrm{deg} / \mathrm{min}$ と設定と して実験を行った。7 deg/min 以上の設定条件ではデータの ばらつきが大きくなり, 安定した結果が得られなかった。

これに対して，1000〜 $2800^{\circ} \mathrm{C}$ 間の熱処理は，昇温速度が 遅いほど平滑な表面を持つ試料となる傾向がある。例えば, 昇温速度を $20 \mathrm{deg} / \mathrm{min}$ 以上にした場合にはボロボロのフィ ルムになり，フィルム形状を保つことがでず，昇温速度を $5 \mathrm{deg} / \mathrm{min}$ 以下にすると外観は図 10 の様に平滑になった。 グラファイト化の反応は昇温速度によって影響をうけるこ とは良く知られており, 昇温速度を遅くすることは高品質 のグラファイトの生成に寄与していると考えられる。この 結果から， $1000^{\circ} \mathrm{C}$ 以上の温度領域での昇温時の温度勾配と して $5 \mathrm{deg} / \mathrm{min}$ と $20 \mathrm{deg} / \mathrm{min}$ を選択しその影響を検討し た。

出発高分子の厚さもこの外観の形状に大きな影響があ り，同じ条件でも厚さが異なれば異なった表面状態のグラ ファイトフィルムになる。フィルムの厚さが薄いほど平滑 な表面状態になりやすく，厚いフィルムほどボロボロの状 態になり易い。表 1 に, 昇温速度を変えて $\mathrm{HTT}=2800^{\circ} \mathrm{C}$ と した場合の処理後の厚さを示す。試料(2)では処理後の厚さ が，試料(1)，(3)，(4)に比べて 2 倍以上に膨らんでおり，上 記の発泡状態となった。そこで, 代表的な例として, 試料 (2)と (3)を用いてさらに詳しい検討を行った。試料(2)の導電 率は, その厚さから単純計算した場合 $5000 \mathrm{~S} / \mathrm{cm}$ である のに対して，試料(3)では $14000 \mathrm{~S} / \mathrm{cm}$ であった。しかし，試 料の見かけの密度が異なることから, 試料(2)の厚さを試料 (3)と同じ $23 \mu \mathrm{m}$ として計算しなおすと, 導電率は 12500 $\mathrm{S} / \mathrm{cm}$ となる。すなわち, フィルムの外観上の違いにも拘わ らず, 試料(2)でも(3)でもほぼ同等の導電性を持つグラファ

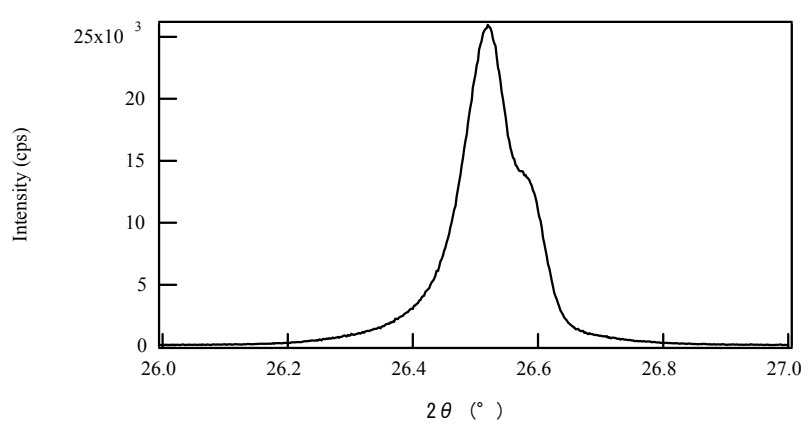

図 12 試料(2)の(002)回折線プロファイル

Fig. 12. Profile of the (002) reflection of the sample(2).

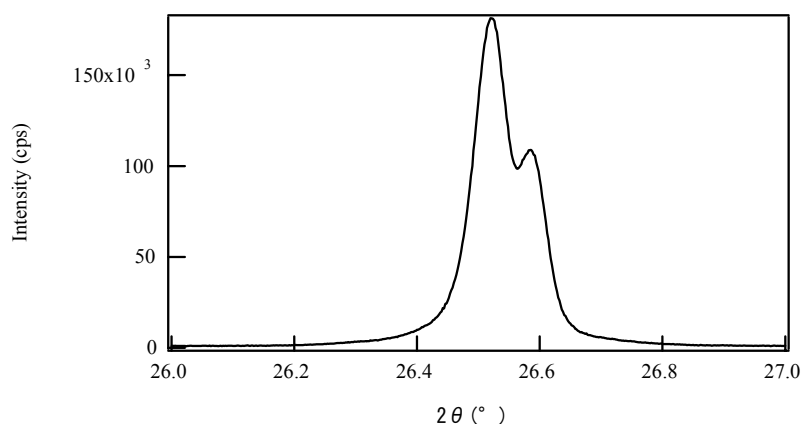

図 13 試料(3)の(002)回折線プロファイル

Fig. 13. Profile of the (002) reflection of the sample(3).

イトが得られていると予想できる。図 12 , 図 13 にはそれ ぞれ試料(2)，試料(3)の X 線反射法によって測定した（002） 回折線のプロファイルを示す。測定は $\mathrm{CuK} \alpha$ 線を使用し, $20 \mathrm{kV}, 10 \mathrm{~mA}$ の条件で行った。その結果, (2)の条件でも (3)の条件でも回折線のピーク位置, 半值幅などに差は観察 されず，この事からいずれの試料でも同程度にグラファイ 卜化反応が進行していると結論した。

〈3.5〉低温電気物性試料(2), (3)における低温電気 物性を測定し, 得られたグラファイトの特性を比較検討し た。図 14 は試料(2)および(3)の低温で導電率比の変化を示す。 なお, この図で縦軸は室温での導電率と各測定温度での導 電率との比を取ったものである。試料(1)でも(2)でも, 室温 から $50 \mathrm{~K}$ までは半導体的に導電率が小さくなるが, $50 \mathrm{~K}$ 付近で伝導度の最小值を示した後, それより低温の領域で は金属的な挙動に変化し導電率が増加する。その特徵は, 従来知られたグラファイト材料に比べて半導体的領域（室 温〜 $50 \mathrm{~K})$ での導電率の温度依存性が非常に大きいことに ある。例えば試料(2)における $\rho 50 / \rho \mathrm{RT}$ は 1.43 であり，試料

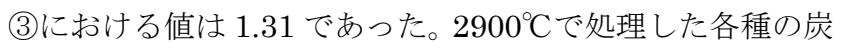
素・グラファイト材料の導電率の温度依存性に関する報告 (23)(24)が成されており，全温度領域で金属的な導電性を示す 材料から全温度領域で半導体的な導電性を示す材料まで各 種の炭素・グラファイト材料の例が知られている。室温で の導電率が試料(2)や(3)とほぼ同等の高い值を示すグラファ 
イト材料においては，常温から $100 \mathrm{~K}$ 付近までの温度依存 性は非常に小さい場合が多い。逆に，試料(2)や(3)の様に $\rho 50 / \rho \mathrm{RT}$ が 1.3〜 1.4 程度の温度依存性をもつ炭素材料では 室温導電率が $5000 \mathrm{~S} / \mathrm{cm}$ 以下で, 全温度領域で半導体的挙 動を示すものがほとんどである。すなわちポリイミドの熱 処理によって得られたグラファイトフィルムは, 常温での 高い導電性, $50 \mathrm{~K}$ 以下での金属的挙動を示すにもかかわら ず，常温〜 $50 \mathrm{~K}$ の範囲では非常に温度依存性の大きい半導 体的な挙動を示すという特徴をもっている。

この様な温度依存性を示す理由は, 先に述べた様にポリ イミドフィルムから得られるグラファイトフィルムが本質 的は $6 \mathrm{~nm}$ 程度の Lc をもつ非常に薄いグラファイト層の集 合体であるためと考えられる。すなわち，一枚のグラファ イト層からなる炭素六角網目構造は本質的に半導体である が, 3 次元結晶においては層間の相互作用によって荷電子 $\pi$ バンドと伝導 $\pi$ バンドがわずかに重なり， $\pi$ 電子が伝導電 子として結晶中を自由に動けるようになる。 $6 \mathrm{~nm}$ 程度の非 常に薄いグラファイト層の場合には電子の動きは二次元的 な電子に近く, グラファイト薄層間での散乱の影響を受け るものと考えられる。

次に, 試料(2)と(3)で $\rho 4.2 / \rho \mathrm{RT}$ の比を比較する。試料(2)に おける $\rho 4.2 / \rho$ RT は 1.31 であるのに対して,試料(3)では 1.20 であり，試料(2)の值の方が大きくなっている。格子久陷の 少ない結晶においては伝導電子の散乱は格子の熱振動であ るフォノンによる散乱と欠陥による散乱に分けて考えられ る。フォノンによる散乱は温度の減少により少なくなり，0 $\mathrm{K}$ では零になるので, 残留抵抗と呼ばれる液体へリウム温 度（4.2 K） と室温での比， $\rho 4.2 / \rho$ RT を比べることにより 結晶の完全性の目安が得られる。すなわち, グラファイト 化の程度が同じでも, その結晶子のサイズや, 結晶子粒界 の欠陥濃度の数が異なる場合にはこの比が異なることにな る。この事から試料(3)の方が試料(2)に比べて格子久陥の少

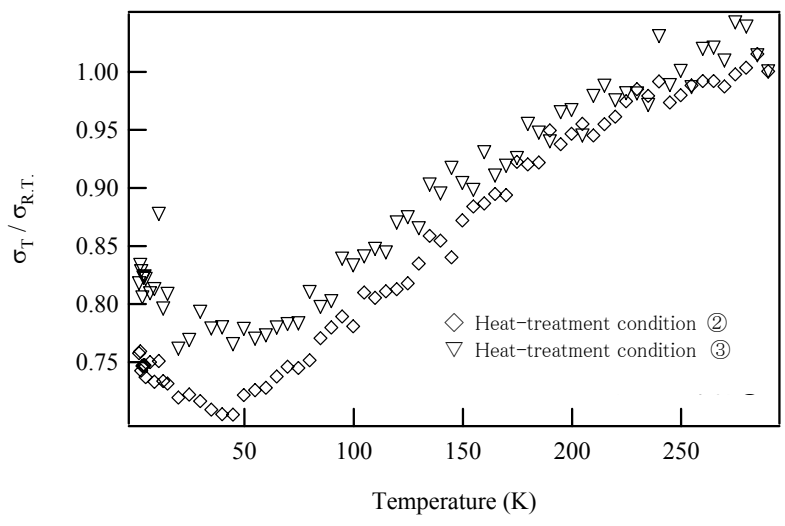

図 14 試料(2)および(3)の導電率比 $\left(\sigma_{\mathrm{T}} / \sigma_{\mathrm{RT}}\right)$ の温度依存性

Fig. 14. Temperature dependences of electrical conductivity ratio, $\sigma \mathrm{T} / \sigma \mathrm{RT}$, of the sample (2) and (3).
ないグラファイトであると考えられる。

この事を確認するために, 試料(2)に対してラビング処理 を施し強制的に格子久陥を導入する操作を行い, その電気 特性に及ぼす影響について測定した。ここで，ラビング処 理とは，例えば試料(2)を一定間隔に設定した二本のローラ 一の間を通すことにより圧縮し, 内部の空気層を押し出す 処理のことを言う。表面に垂直方向から圧縮する方法では シワを作ってしまう場合が多々あり, シワを追い出すよう に圧縮する必要がある。本稿ではこのような操作をラビン グ処理と呼ぶことにした。この様な処理を加えることによ り試料(2)の厚さは $30 \mu \mathrm{m}$ となった。図 15 にはこの様なラ ビング処理をおこなった試料における低温での導電率の温 度依存性を示す。なお室温での導電率は厚さ $30 \mu \mathrm{m}$ を仮定 して算出したが，ラビング処理によって室温での導電率そ のものは殆ど変化しなかった。このラビング試料における $\rho 50 / \rho \mathrm{RT}, \rho 4.2 / \rho \mathrm{RT}$ 比, を計算すると, それぞれの值は $1.59,1.46$ になり, 試料(2)に比べていずれの比も増加する ことが分った。この様にラビング処理により強制的にグラ ファイト層に歪を導入することによってそれぞれの比率が 増加することが確認できたので, 試料(2)と試料(3)の電気特 性の違いは格子欠陥の量の違いであると結論した。

〈3.6〉柔軟性フィルムの作製とその物性先に述心 たラビング処理によって, 試料(2)における部分的に結合し たグラファイトフィルム薄層間を剥離し柔軟性を持たせる ことが可能になる。また図 16 には試料(2)のラビング後の外

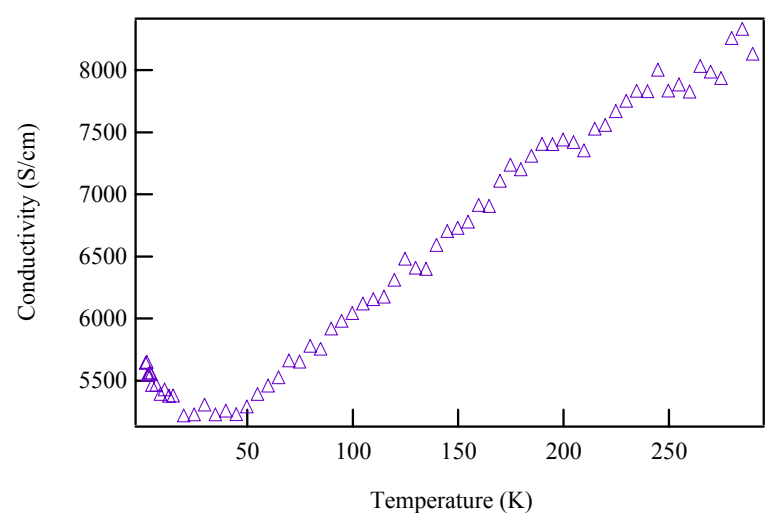

図 15 試料(2)のラビング後の導電率の温度依存性

Fig. 15. Temperature dependences of electrical conductivity of the sample (2) after rubbing.
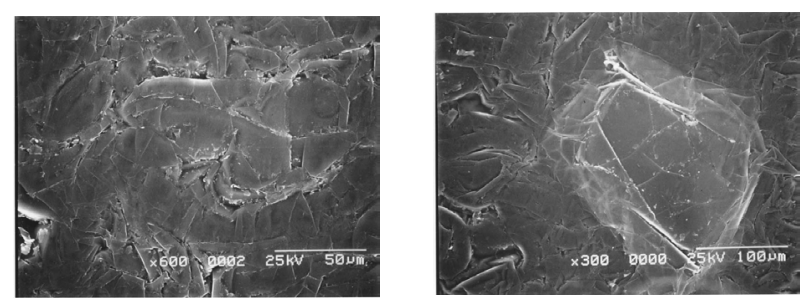

図 16 試料(2)のラビング後の表面 SEM 写真

Fig. 16. Scanning electron microscope image of the sample (2) after rubbing. 
表 2 試料(2)のラビング前後での柔軟性比較

Table 2. Flexibility of the sample (2) after rubbing.

\begin{tabular}{|c|c|c|}
\hline & Initial & After rubbing \\
\hline Thickness $(\mu \mathrm{m})$ & 55 & 34 \\
\hline Density $\left(\mathrm{g} / \mathrm{cm}^{3}\right)$ & 0.8 & 1.3 \\
\hline Bending $(\mathrm{cycles})$ & 15 & $10000 \sim$ \\
\hline
\end{tabular}

表 3 ポリイミド由来のグラファイトシートと市販 エキスパンドグラファイトシートの物性比較

Table 3. Physical properties of various graphite sheets, graphitized polyimide sheets and commercially available expand graphite sheets.

\begin{tabular}{|c|c|c|}
\hline & $\begin{array}{c}\text { Including } \\
\text { graphitized } \\
\text { polyimide sheets }\end{array}$ & $\begin{array}{c}\text { Commercially } \\
\text { available expand } \\
\text { graphite sheets }\end{array}$ \\
\hline Density $\left(\mathrm{g} / \mathrm{cm}^{3}\right)$ & $1.0 \sim 1.3$ & 1.0 \\
\hline $\begin{array}{c}\text { Compression } \\
\text { ratio(\%) }\end{array}$ & 71.3 & 44.4 \\
\hline $\begin{array}{c}\text { Compression } \\
\text { recovery}(\%)\end{array}$ & 76.5 & 34.2 \\
\hline $\begin{array}{c}\text { Extensional } \\
\text { strength(Pa) }\end{array}$ & $2.0 \times 10^{7}$ & $2.0 \times 10^{6}$ \\
\hline Bending(cycles) & $10000 \sim$ & 20 \\
\hline
\end{tabular}

観を示す。図 11 との比較から内部の空気層が押し出された 様子がわかる。

この様な処理が可能であるのは, $2600^{\circ} \mathrm{C}$ 以上の加熱処理 がなされ, ラビング処理前の見かけ密度が $0.66 〜 1.5$ の範囲 に発泡したものである。処理温度が $2600^{\circ} \mathrm{C} よ り$ 低い場合や 見かけの密度が 1.5 よりも大きいものはラビング処理を施 しても柔軟性のあるフィルムは得られなかった。表 2 は, ラビング処理前後でのフィルムの柔軟性を比較するために 耐折強度試験を行った結果である。ラビング処理した試料 では 10000 回の耐折試験でも破壊は起きず，この様な処理 によって優れた柔軟性が付与されることが分った。

グラファイト化ポリイミドのラビング処理によって得ら れたグラファイトシートと膨張グラファイトから作成され た市販のグラファイトシートの物性とを比較して表 3 に示 す。ラビング法によって得られたグラファイトシートは, 従来の方法で製造された人工グラファイトシートに対し て, 引っ張り強度, 圧縮率，復元率，などの点ではるかに 優れた物性を有しており, 例えばその引っ張り強度は 10 倍 に達する。圧縮率と復元率は， $0.7 \mathrm{Mpa}$ で 15 秒加圧後の厚 さを $\mathrm{t}_{1}, 34.3 \mathrm{Mpa}$ で 60 秒加圧後の厚さを $\mathrm{t}_{2}$, 再び $0.7 \mathrm{Mpa}$ までもどし 60 秒経過後の厚さを $\mathrm{t}_{3}$ とした場合,

圧縮率 $(\%)=\left(\left(\mathrm{t}_{1}-\mathrm{t}_{2}\right) / \mathrm{t}_{1}\right) \times 100$

復元率 $(\%)=\left(\left(\mathrm{t}_{3}-\mathrm{t}_{2}\right) /\left(\mathrm{t}_{1}-\mathrm{t}_{2}\right)\right) \times 100$

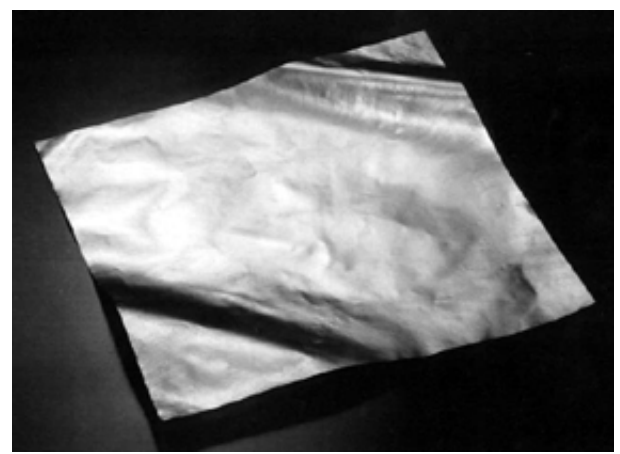

図 17 ポリイミドのグラファイト化によって 得られたグラファイトシート

Fig. 17. Graphite sheet obtained from polyimide film.

で表した数值である。この様な優れた機械的特性と優れた 柔軟性が実現できた理由は, ポリイミドフィルムの熱処理 法によって得られたグラファイトが本質的に $\mathrm{L}_{\mathrm{C}}=6 \mathrm{~nm}$ 程 度の極めて良質のグラファイト薄層の集合体として生成す るということによっている。すなわち，この様なグラファ イトフィルムを密度が $0.6 〜 1.5$ の範囲になるように熱処理 プロセスを制御し，そのグラファイト層を破壊することな く層間に空気層を導入し，さらにラビング処理によってグ ラファイト薄層間を剥離させたことによる。ラビング処理 によってグラファイト層間の剥離を促進し，層間にズレを 起こす自由度を与え, 柔軟性を付与することができるので ある。図 17 には, この様な手法で得られたグラファイトシ ートの一例を示す。

\section{4. 結論}

高温熱処理によるポリイミドフィルムのグラファイト化 過程は, $500 \sim 600^{\circ} \mathrm{C}$ で熱分解, $800^{\circ} \mathrm{C}$ 付近で炭化, $2200^{\circ} \mathrm{C}$ を超えた付近でグラファイト化が始まる。それを導電率変 化, 音速・ヤング率変化, X線回折, 透過型電子顕微鏡等 により観察した。このグラファイト化反応の特徴は, 炭素 六角網目構造がフィルム面に平行になるように, かつ反応 部分は不均一に起こり, 最終的には厚さ $6 \mathrm{~nm}$ 程度の極めて 良質のグラファイト薄層の集合体となることである。熱処 理プロセスの制御により外観や厚さの異なる試料を作製で き，見かけの密度が $0.6 〜 1.5$ になるように熱処理すること でグラファイト薄層を破壊することなく, グラファイト薄 層束間に空隙が存在する構造とすることができる。この様 なフィルムをラビング処理することで層間にズレを起こす ことができる自由度を与え，柔軟性に富む高品質のグラフ アイトシートを得ることができた。この様な手法で人工的 に作製した高品質グラファイトシートは従来のエキスパン ドグラファイトを用いて製造された人工グラファイトシー トに対して引っ張り強度, 圧縮率, 復元率, 熱伝導性, 導 電性などの点ではるかに優れた物性を有している。このグ ラファイトシートは, その高い熱伝導性と異方性を利用し 
た熱伝導材（放熱材）として，今後ますますその工業的な 価值を増すであろう。

(平成 15 年 1 月 31 日受付, 平成 15 年 5 月 22 日再受付)

\section{文献}

（1）村上ら：高分子学会第 34 回高分子討論会予稿集, P2929（1985）; 大西ら：日本化学会第 50 春季年会要旨集， $3 Z 37 （ 1985)$

(2) M. Murakami, K. Watanabe, and S. Yoshimura : Appl. Phys. Lett., Vol.48, No.23, p.1594 (1986)

(3) M. Murakami and S. Yoshimura : Synth. Met., Vol.18, p.509 (1987)

(4) M. Inagaki, T. Takeichi, Y. Hishiyama, and A. Oberin : Chem. Phys. Carbon, Vol.26, p.245 (1999)

(5) M. Inagaki, M. Sato, T. Takiguchi, A. Yoshida, and Y. Hishiyama : Carbon, Vol.30, p.903 (1992)

(6) T. Takeichi, Y. Eguchi, Y. Kaburagi, Y. Hishiyama, and M. Inagaki : Carbon, Vol.36, p.117 (1997)

(7) T. Takeichi, Y. Eguhci, Y. Kaburagi, Y. Hishiyama, and M. Inagaki : Carbon, Vol.37, p.569 (1999)

(8) M. Hasegawa, T. Matano, Y. Shindo, and T. Sugimura : Macromolecules, Vol.29, p.7897 (1996)

(9) T. Takeichi, M. Zuo, and M. Hasegawa : J Polym. Sci. PartB: Polym. Physics, Vol.39, p.3011 (2001)

（10）塩谷正俊・篠谷賢一・鞠谷雄士・高久 明 : 炭素材料学会年会費要 旨集, Vol.18th 42-43 (1991)

(11) I. Murase, T. Ohnishi, T. Noguchi, and M. Hirooka : Polymer Common., Vol.25, p.327 (1984)

(12) T. Ohnishi, I. Murase, T. Noguchi, and M. Hirooka : Synthetic Metals, Vol.14, p.207 (1986)

(13) T. Ohnishi : Taoso, No.129, pp.81-90 (1987)

(14) H. Ueno and K. Yoshino : J. Phys. Soc. Jpn., Vol.55, p.4384 (1986)

(15) K. Yoshino, H. Ueno, F. Uesugi, and M. Satoh : J. Appl. Phys., Vol.61, p.1493 (1987)

(16) M. Murakami, N. Nishiki, K. Nakamura, J. Ehara, H. Okada, T. Kouzaki, K. Watanabe, T. Hoshi, and S. Yoshimura : Carbon, Vol.30, No.2 (1992)

(17) A. W. Moore : "Highly Oriented Pyrolytic Graphite", Chemistry \& Physics of Carbon, Vol.11, Marcel Dekker, Inc. (1973)

(18) K. Ohno, M. Murakami, T. Hoshi, Y. Kobayashi, T. Shoji, and T. Arai : Advance in X-ray Analysis, Vol.37, p.545 (1994)

(19) T.Hoshi and M.Murakami : National Technical Report, Vol.40, No.1, p.74 (1994)

(20) K.Yoshino and H.Ueno : Tanso, No.136, pp.29-43 (1989)

（21）羽島浩章 - 山田能生・白石 稔: 資源環境技術総研報告, No.17, p.71 (1996)

(22) A. Buerger, E. Fitzer, M. Heym, and B. Terwiesch : Carbon, Vol.13, p.149 (1975)

(23) I. L. Spain, A. R. Ubbelohde, and D. A. Young : "Electronic properties of oriented graphite", Philosophical Trans. Royal Society

(24) T. C. Chieu, M. S. Dresselhaus, and M. Endo : Phys. Rev. Vol.B26, p.5867 (1982)

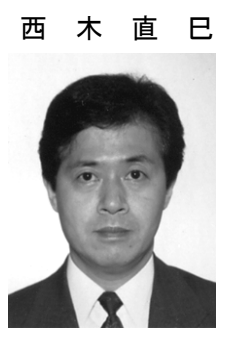

(非会員) 81 年 3 月信州大学工学部機械工学 科卒業。8 3 年同大学大学院工学研究科修士課程 修了。同年 4 月松下電器産業(株入社。アルミ電 解コンデンサの工法開発, グラファイト材料の 開発に従事。

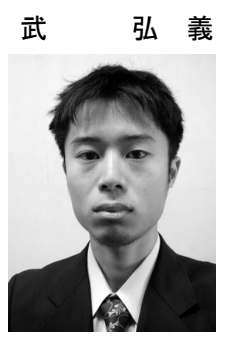

(正員) 99 年 3 月大阪大学工学部電子工学科 卒業。同年 4 月同大学工学研究科電子工学専攻 博士前期課程進学。01年 3 月同研究科修了。同 年 4 月大阪大学大学院工学研究科電子工学専攻 博士後期課程進学, 日本学術振興会特別研究員。 機能性新規炭素材料に関する研究に従事。02 年 電気関係学会関西支部連合大会奨励賞受賞。電 気学会, 応用物理学会会員。

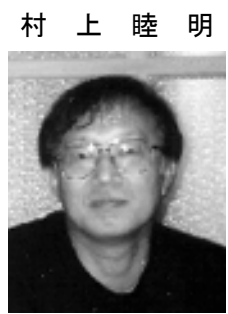

(非会員) 70 年 3 月愛媛大学工学部工学研究 科修士課程終了。同年 4 月松下電器産業(森入社。 松下技研㑣)出向。0 01 年 7 月松下電器産業㑣退 社。同年 8 月鐘淵化学工業侏入社, 現在, 同社 エレクトロニクス研究所, 上席幹部職。理学博 士。主として導電性有機物, 炭素・グラファイ 卜材料, 機能性有機電子材料の開発に従事。

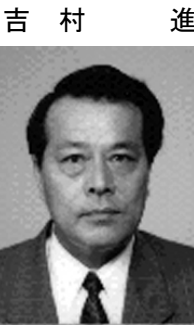

（非会員） 64 年 3 月東京大学工学部電子工学 科卒業。同年 4 月松下電器産業(㑣入社。松下技 研㑣)出向。99 年 6 月(財)地球環境産業技術研究 機構出向。01 年松下電器産業(株)定年退職。(財) 地球環境産業技術研究機構参与。大阪大学客員 教授。長崎総合科学大学理事・客員教授。松下 電器産業(㑣)客員。理学博士。主として有機半導 体, 導電性高分子, グラファイト材料の基礎研 究と工業的応用に従事。日本物理学会, 高分子学会会員。

吉 野 勝 美 （正員） 64 年大阪大学工学部電気工学科卒業。

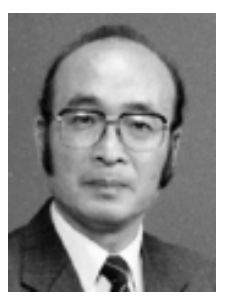
69 年同大学院工学研究科博士課程修了。同年大 阪大学工学部助手。 88 年同教授。 96 年から 2000 年東北大学工学部電子工学科教授兼任。7 74 年加 ら 1 年間, ベルリン, ハーンマイトナー原子核 研究所客員研究員。長崎総合科学大学客員教授, 工学博士。主として, 導電性高分子, 絶縁体高 分子, 光機能性高分子, 液晶, 液体, 強誘電体 などの電気電子材料に関する研究に従事電気学会会員, 電気学会元 副会長, 日本液晶学会元会長。 